\title{
"Dead in White Clothes": Modes of Christian Expression on Viking Age Rune Stones in Present-Day Sweden
}

\author{
By Henrik Williams 2009
}

(Submitted version - the early author's version that has been submitted to the journal/publisher). Published as: Williams, Henrik: "Dead in White Clothes": Modes of Christian Expression on Viking Age Rune Stones in Present-Day Sweden. I: Epigraphic Literacy and Christian Identity: Modes of Written Discourse in the Newly Christian European North. Ed. by Kristel Zilmer \& Judith Jesch. (Utrecht Studies in Medieval Literacy 4.) Turnhout 2012. Pp. 137-152.

Practical literacy and Christian identity are two sides of the same coin when dealing with late Viking age rune stones. Reading the inscriptions on these monuments are by necessity not a straight-forward process for us today. The printed word we are familiar with is different in so many ways when compared to the usually very short and sometimes enigmatic messages we encounter in the form of runic carvings on rocks and cliffs throughout Scandinavia.

The difficulties which we expect and take into account are not, however, primarily the main obstacles to our complete understanding of the rune stone texts. In one respect, these problems are superficial, dealing with formal restrictions of the media and the writing system. As is well known, the Viking age runic characters only numbered 16 (with the addition of three optional variants. Since the language(s) contained quite a few speech signs more than that, most runes could be use with more than one value and it is up to the reader to determine exactly which. Further complications include that long consonants and sometimes even the separation of word was omitted. Since these writing imperfections involve a thousand-year old language continuum, the interpretation of any single inscription can be a quite hard task. ${ }^{1}$

But, these difficulties are, as I have already said, expected. More devious, perhaps, is the difference between the world then and now. We simply do not have the same points of reference with which to orient ourselves to create the proper understanding of background and context.

\footnotetext{
${ }^{1}$ H. WILLIAMS, "Runes", The Viking world, ed. S. BRINK in collaboration with N. PRICE (London \&
} New York, 2008), pp. 281-290, at pp. 281-283. 
"Dead in White Clothes": Modes of Christian Expression on Viking Age Rune Stones in Present-Day Sweden. Preprint version. Henrik Williams, Uppsala University, 2010

The communication principles of Viking age runic literacy has been discussed by Rune Palm. ${ }^{2}$ He utilizes a model ${ }^{3}$ in which the writer forms a message by steps proceeding from ordering reality into a message, through formulating this as sentences, words and speech sounds, to the actual runes carved in stone. A reader decoding the message starts in the opposite direction with the runic characters and proceed towards understanding, but will require an extra step, a proposition of what the inscription is believed to be about. This the writer already knew, of course.

There is no such thing as a "blank" mind when it comes to a specific reader at a particular time reading a certain text in a precise place. We always need to make propositions: what is this text likely to say? This is true of the Viking age reader, and it is certainly true for us. Still, I feel that this is often forgotten when approaching the messages on the runic monuments from the 11th and early 12th century.

One problem lies in "false friends", i.e. words in a runic text that are etymologically the same as a corresponding word today. A single example may suffice: The runic Swedish word drœngR is identical to Modern Swedish dräng. The latter means 'farmhand', in Southern Swedish also 'boy'. But the former certainly had a different meaning, possibly 'young warrior or member of a retinue' or 'just as a term of praise for (usually young) men'. 4 The contemporary reader presumably had a pretty firm idea of the precise meaning. We do not.

We therefore need to be humble when discussing the exact meaning of any particular rune stone, especially before we claim to have narrowed down the exact meaning of a significant word. This is even more important to bear in mind when we try to build a discussion on such a precise meaning. Before we delve further into the social position of the drcengR mentioned above and construct a society in which he fits, we certainly need to ascertain exactly what a drcengR was during the Viking age and in the part of Scandinavia

${ }^{2}$ R. PALM, ”Ráði drengr paR rýnn sé. Några tankar om ”Runacy“”, Nordiska språk - insikter och utsikter. Föredrag från det 5:e studentkollokviet i nordisk språkvetenskap. Berlin 6. - 7 Mai 2000, ed. J. KUSMENKO \& S. LANGE (Berlin, 2001), pp. 110-123.

${ }^{3}$ PALM, “Ráði drengr paR rýnn sé”, pp. 112-120.

${ }^{4}$ An English Dictionary of Runic Inscriptions in the Younger Futhark, http://runicdictionary.nottingham.ac.uk/index.php (accessed 2 January 2010), entry sub voce drcengR. 
"Dead in White Clothes": Modes of Christian Expression on Viking Age Rune Stones in Present-Day Sweden. Preprint version. Henrik Williams, Uppsala University, 2010

where the runic memorial is found. ${ }^{5}$ In fact even not so significant words can be quite important. $^{6}$

The Christian vocabulary is a particularly difficult semantic field, although though we have contemporary Continental and some 12th century and later Scandinavian sources informing us of the theology at the time. Even the words and and sial are of uncertain denotation in spite of the fact that they are retained as Modern Swedish ande 'spirit' and själ 'soul'. 7

One expression which, however, there is little doubt as to its precise meaning is the Runic Swedish dauðr i hvitavaðum, literally 'dead in white cloth/clothes'. This is a recurring expression on some rune stones exclusively from the province of Uppland (north of Stockholm). The established interpretation is that we are dealing with baptismal robes which were "worn by the convert at his baptism and for a week afterwards. The Upplanders in whose memory this group of rune stones was put up were thus baptized on their deathbed. It is the missionary period, the age of conversion, that we encounter in these inscriptions”. ${ }^{8}$

Seven runic memorials give witness to the expression:

Molnby (U 243, now lost): ${ }^{9}$ Holmlaug[R] ok Holmfrið[r] lata ræisa stæina æeftiR Fasta ok Sigfast, sunu sina. DœiR dou i hvitavaðum.

Holmlaugr and Holmfríðr have raised the stones in memory of Fasti and Sigfastr, their sons. They died in christening robes.

\footnotetext{
${ }^{5}$ Cf. J. JESCH “Still standing in Ågersta: textuality and literacy in late Viking-Age rune stone
} inscriptions, Runeninschriften als Quellen interdisziplinärer Forschung. Abhandlungen des Vierten internationalen Symposiums über Runen und Runeninschriften in Göttingen vom 4.-9. August 1995, ed. K. DüWEL (Berlin/New York, 1998: Ergänzungsbände zum Reallexikon der germanischen Altertumskunde 15), pp. 462-475, at p. 468 .

${ }^{6}$ K. ZILMER “On the symbiosis of orality and literacy in some Christian rune stone inscriptions”, Á austrvega. Saga and East Scandinavia. Preprint papers of The 14th International Saga Conference, ed. A. NEY, H. Williams \& F. CHARPENTIER LJUNGQVIST (Gävle, 2009: Papers from the Department of Humanities and Social Sciences, University of Gävle 14), pp. 1074-1081, at p. 1075 with refs. Also available at http://www.saga.nordiska.uu.se/preprint/

${ }^{7}$ B. LA FARGE, ,Leben’ und ,Seele’ in den altgermanischen Sprachen: Studien zum Einfluß christlichlateinischer Vorstellungen auf die Volkssprachen (Heidelberg, 1991: Skandinavistische Arbeiten 11).

8 S.B.F. JANSSON, Runes in Sweden (Stockholm, 1987), p. 112.

${ }^{9} \mathrm{U}+$ number indicates inscription with publication number that has been published in the edition of Swedish runic inscriptions from Uppland, E. WESSÉN \& S.B.F. JANSSON, Upplands runinskrifter (Stockholm, 1940-1958: Sveriges runinskrifter 6-9). 
"Dead in White Clothes": Modes of Christian Expression on Viking Age Rune Stones in Present-Day Sweden.

Gådersta (U 364, ATA Dnr 4374/50): Karsi ok ... sinn. Hann vaR dauðr i hvitavaðum. Karsi and ... their ... He died in christening robes.

Torsätra (U 613): Un(n)a let ræisa pennsa stæin æftiR sun sinn Øystæin, sum do i hvitavaðum. Guð hialpi salu hans.

Una(n)a had this stone raised in memory of his son Eysteinn who died in christening robes. May God help his soul.

Amnö (U 699): Ingilæif let ræisa stæin at Bruna, boanda sinn. Hann varð dauðr a Danmarku i hvitavaðum. Balli risti.

Ingileif had the stone raised in memory of Brúni, her husband. He died in christening robes in Denmark. Balli carved.

Håga (U 896): ... [l]etu ræisa stæin fyr and ØyndaR (?), sun sinn, dauðr [i] hvitavaðum i Danma[rku] (?) ... Reð runaR ØpiR.

... had the stone raised for the spirit of Eyndr (?), their son, (who) died in christening robes in Denmark (?) ... Epir arranged the runes.

Tensta k:a (U 1036): Sigfastr ok Brandr ok Vikætill. Hælga let retta stæin æeftiR Andvett, sun sinn, sum [vaR] dauðr [i] hvitavaðum. Kristr hialpi sial Andvetta[R].

Sigfastr and Brandr and Véketill. Helga had the stone erected in memory of Andvéttr, her son, who died in christening robes. May Christ help Andvéttr’s soul.

Uppsala domkyrka: ${ }^{10}$... letu retta stæin penna ... [hvi]tavaðum ... æigi verða, meðan $\operatorname{stcin}[a R](?)$...

... had this stone erected ... christening robes ... no ... will be while the stones (?) ...

After a false start when the expression dauðr i hvitavaðum was thought to be the name of a place where people had been killed, runologists reached a consensus already in the 19th century as to the meaning of hvitavaðir. It was identified with the expression í hvítaváðum in

\footnotetext{
${ }^{10}$ H. GUSTAVSON in E. SVÄrdDSTRÖM \& H. GUSTAVSON, “Runfynd 1972”, Fornvännen 68 (1973), pp.
} 185-203, at p. 194. 
"Dead in White Clothes": Modes of Christian Expression on Viking Age Rune Stones in Present-Day Sweden. Preprint version.

Old Norse. In the Cleasby-Vigfusson dictionary this expression is found under the headword hvítr. One reads inter alia: ${ }^{11}$

Eccl[esiastical] use of the word white: I. at the introduction of Christianity, neophytes in the week after their baptism used to wear white garments, called hvita-váðir, f. pl. white weeds, as a symbol of baptism c1easing from sin and being a new birth[...]: the Sagas contain many touching episodes of neophytes, esp. such as were baptized in old age, and died whilst in the white weeds[.]

A number of instances of this practice are then mentioned, and the dictionary goes on to say that: ${ }^{12}$

Sweden, but above all Gothland, remained in great part heathen throughout the whole of the 11th century, after the neighbouring countries Denmark and Norway hade become Christian, and so we find in Sweden Runic stones referring to Swedes who had died in the white weeds, some abroad and some at home[.]

This picture is then repeated in the treatment of the individual runic inscriptions. Sven B.F. Jansson writes: ${ }^{13}$

Det är av stort intresse, att på sex uppländska runstenar finna omtalade män, som ha dött $i$ hvitavaðum, Uttrycket tillhör missionstiden, en kort begränsad tid, då det var vanligt, att människor inför döden togo det avgörande beslutet att övergå från hedendomen till kristendomen. Då de anhöriga ha funnit angeläget att i minnesinskrifterna omtala detta, vittnar det om att de själva högt värdesatt dopet och att sålunda kristendomen har gjort ett djupt intryck på dem.

(It is of great interest to find mentioned on six Upplandic rune stones men who have died $i$ hvitavaðum. The expression belongs to missionary times, a period of short duration when it was common for people to take the conclusive decision to change from Paganism to Christianity before dying. Since the relatives found it important to mention this, it is a witness of their own high evaluation of baptism and hence that Christianity had made a deep impression on them.)

${ }^{11}$ An Icelandic-English Dictionary Based on the Ms. Collection by the Late Richard Cleasby. Enlarged and Completed by Gudbrand Vigfusson (Oxford, 1874), p. 302.

${ }^{12}$ An Icelandic-English Dictionary, ibid.

${ }^{13}$ In E. WESSÉN \& S.B.F. JANSSON, Upplands runinskrifter 1 (Stockholm, 1940: Sveriges runinskrifter 6), p. 408. 
"Dead in White Clothes": Modes of Christian Expression on Viking Age Rune Stones in Present-Day Sweden. Preprint version.

Jansson also writes: ${ }^{14}$

Även i formellt avseende är uttrycket $i$ hvitavaðum av intresse. Det är gemensamt nordiskt, utan tvivel stämplat i något centrum för missionen och därifrån spritt till Uppland och till Island.

(Also in a formal sense is the expression $i$ hvitavaðum of interest. It is commonly Scandinavian, without doubt coined in some missionary centre and from thence spread to Uppland and to Iceland.)

Elias Wessén later adds the observation that of the six examples of inscriptions containing hvitavaðir four are erected for a son or sons, one for a husband, and one probably for a brother: ${ }^{15}$

Detta tyder på att det är unga män, som har fått detta eftermäle: han blev död i dopkläder. I intet fall förekommer det, att söner ha rest minnesvård över sin fader, vilket annars är det vanligaste och naturligaste. Förmodligen ha de unga männen dragit ut i främmande land, på köpmansfärd eller vikingatåg, och de ha sedan icke återvänt. Budskapet om deras död har kommit hem, men tillika den hugnesamma underrättelsen, att de hade mottagit det heliga dopet, innan de gingo hädan. Detta har de anhöriga funnit angeläget att meddela i minnesorden. Det vittnar om att de själv aha varit kristna, men att dopet dock var något ovanligt och anmärkningsvärt. Ur missionstidens förhållanden blir detta begripligt. Folket i Uppland var under runstenarnas tid till övervägande del kristet, men endast på få platser inom landet fanns det ännu kyrkor och bofasta präster, som hade rätt att meddela sakramenten och utföra de heliga handlingarna. Det var icke lätt att bli döpt, om man ville det aldrig så gärna. Annorlunda var det för dem som foro utomlands, till kontinenten eller till England. Ja, redan i Danmark stodo kyrkans alla välsignelser till buds.

(This is an indication that it is young men who are given this obituary. In none of the cases does it occur that sons have erected the monument after their father, which otherwise is the most common and natural. The young men have probably gone off to foreign lands, on trade or Viking expeditions, and have then not returned. The news of their death has gotten home, but also the comforting tidings that they had received holy baptism before they died. This the relatives found important to announce in the commemorative words. It is a witness of their own Christianity but also that baptism was something rare and noteworthy. In the situation of the missionary period this is understandable. The people of Uppland were to a large extent Christians, but only in a few places in

\footnotetext{
${ }^{14}$ In WESSÉN \& JANSSON, Upplands runinskrifter, p. 409.

${ }^{15}$ In E. WESSÉN \& S.B.F. JANSSON, Upplands runinskrifter 1 (Stockholm, 1958: Sveriges runinskrifter 9), pp. 280-281).
} 
"Dead in White Clothes": Modes of Christian Expression on Viking Age Rune Stones in Present-Day Sweden. Preprint version.

the country were there yet any churches and stationary priests who had the right to issue the sacraments and perform the holy acts. It was not easy to get baptized, however dearly you wanted to. It was different for those who went abroad, to the Continent or to England. Yes, already in Denmark all the blessings of the Church were available.)

As you can see, focus may have shifted slightly different between Jansson and Wessén. The former seems to imply that the surviving relatives may not have been Christians themselves, if I read him correctly, whereas Wessén firmly states this to be so.

As far as I know, no one has in print challenged the interpretation of the expression dauðr i hvitavaðum, nor the explanation of what it refers to.

In 2007 an archaeologist at Uppsala University, Annika Larson, wrote a doctoral dissertation: Warriors Clothing. Shift in Scandinavian costume in vicinity of year 1000, to quote the title it was given in English. ${ }^{16}$ In it she devotes an entire, if brief, chapter to the expression i hvitavaðum. ${ }^{17}$ Her interest was aroused by the textile term, but as elsewhere in the dissertation she uses the old textiles as a point of departure into a much wider range of issues connected to the Christianization process. As all other scholars before her, Larsson sees the mentioning of baptismal robes as an indication of recently christened adults and she repeats and adds textual passages referring to such practices in Viking age Scandinavia, Iceland and on the Continent. But after citing the latter part of the passage from Wessén (vide supra) she goes one step further and wonders: ${ }^{18}$

Så tolkade man för 50-60 år sedan. En enkel och ofta använd metod för att pröva rimligheter i antaganden är att ställa frågan: — Vad skulle hända om det vore tvärtom? Kan det möjligen redan under runstenstid ha dragit skam och vanära över en familj när någon dött utan att vara döpt? Jag föreslår att det under runstenstid i Uppland var viktigt att tala om för samhället att man var rätt och riktigt döpt in i den kristna gemenskapen - inte för att det var ovanligt och statushöjande, utan för att det kan ha varit nödvändigt för familjens överlevnad och framtid.

${ }^{16}$ A. LARSSON, Klädd krigare. Skifte i skandinaviskt dräktskick kring år 1000, (Uppsala, 2007: Occasional Papers in Archaeology 39).

${ }^{17}$ LARSSON, Klädd krigare, p. 332, also wants to add an eighth inscription to the corpus, the fragmentary rune stone found at the hospital in Uppsala. However, the runes uap stand alone and are probably not to be interpreted as part of the word hvitavaðir. LARSSON erroneously claims that this inscription is unpublished, vide M. ÅHLÉN in TH. SnÆDAL, M. STOCKLUnd \& M. ÅHLÉN “Runfynd 1987”, Fornvännen 83 (1989), pp. 234-250, at p. 243.

${ }^{18}$ LARSSON, Klädd krigare, p. 340. 
"Dead in White Clothes": Modes of Christian Expression on Viking Age Rune Stones in Present-Day Sweden. Preprint version.

Henrik Williams, Uppsala University, 2010

(Thus one interpreted 50-60 years ago. A simple and frequently used method to test the plausibility of assumptions is to put the question: What if it were the other way around? Could it possibly have brought shame and dishonour upon a family already during the time of the rune stones if someone died without being baptized? I suggest that in Uppland during the time of the rune-stones it was important to let society know that you were properly and correctly baptized into the Christian community - not because it was uncommon and lent to a higher status, but because it may have been necessary for the survival and future of the family.)

Larsson reminds us that according to early Danish laws an unbaptized person was not entitled to inherit, and she posits that this meant an indirect baptismal compulsion for landed families. ${ }^{19}$ The reason behind mentioning that your son was baptized was that in this way you as a parent could inherit him, even if he were buried in a mound but not, as is evident, as a heathen. She claims that this was an efficient means for the king to enforce Christianization and thereby ensure their power. ${ }^{20}$ The rune-stones then served the purpose of "warding off" the representatives of the king from claiming the inheritance of young men who had died childless: "Otherwise the ironclad men in power might burn the property or claim it for themselves." 21

Let us begin by scrutinizing Larsson’s new take on the expression dauðr i hvitavaðum. If it were correct, would we not expect there to be many more rune stones asserting that the deceased had been properly baptized? It must not have been less important when it came to other dead relatives, including parents, since baptism was likely a prerequisite for all inheritance. But even if we restrict ourselves to cases of those who died without off-spring only seven inscriptions is a remarkably low number. And why are there no rune stones outside Uppland which carry the expression dauðr i hvitavaðum? Larsson does not address these questions. The fact that the baptism requirement is mentioned in various provincial laws indicates that it was not a regulation restricted to Uppland, in fact we have no trace of it there.

In a way it is strange axiom that the expression dauðr i hvitavaðum refers to newly baptized persons, as there is quite a bit of evidence showing that we may reckon with the presence of a rather advanced Christianity in Viking Age Sweden. We no longer believe as did Cleasby-Vigfusson (vide supra) that Sweden "remained in great part heathen throughout the whole of the 11th century".

\footnotetext{
${ }^{19}$ LARSSON, Klädd krigare, p. 343.

${ }^{20}$ LARSSON, Klädd krigare, p. 345.

${ }^{21}$ LARSSON, Klädd krigare, p. 355.
} 
"Dead in White Clothes": Modes of Christian Expression on Viking Age Rune Stones in Present-Day Sweden. Preprint version.

That, however, is certainly not true for all of Sweden. Västergötland must have been almost fully Christianized no later than the turn of the millennium when the province even had its own bishop, and Christianity was obviously quite strong in Uppland already in the early eleventh century. In fact, the inscriptions mentioning the expression dauðr i hvitavaðum are remarkably Christian. All of the seven stones are marked with a cross, and two carry prayers. They also date from a period when Christianity should have been fairly well established in Uppland. Six of the stones are dated to the second half of the 11th century, i.e. are fairly late. The seventh (U 896) has been given an earlier dating, but possibly erroneously.

Thus, there is reason to presume not only a quite early establishment of Christianity among the leading families of Uppland, although the process took a century to run its full course, but also a rather advanced state of the faith and theology, which rhymes badly with the idea of very recent conversion. One way of proving this is by studying the prayers on Swedish rune-stones, which are very common. Out of 397 predicate verbs, 93\% are constituted by help, but there are 12 other verbs, most of which are unique. ${ }^{22}$ This reminds us of the Norwegian stone from Galteland with its concluding prayer "God is one”, a quote from the New Testament. ${ }^{23}$ By studying the Swedish prayers that are unique we get the picture of a rather devout society:

U 323 May God help his spirit and soul, forgive him (his) guilt and sins.

U 512 May God and God's mother help their spirits and souls better than they have done.

U 478 May Michael protect his spirit.

U 160 May God and God's mother help his spirit and soul; grant him light and paradise.

U 942 May God bless us, the ruler of men, holy Lord.

U 519 May God see (him). ${ }^{24}$

U 719 May Christ let Tum(m)i’s spirit come into light and paradise and into the best home for Christians.

U 909 May God have mercy

\footnotetext{
${ }^{22}$ L. Olsen, Nordens vikingatida runstensböner, BA thesis, Uppsala University, 2004, p. 13.

${ }^{23}$ M. OLSEN, Norges innskrifter med de yngre runer 3 (Oslo, 1954), p. 32

${ }^{24}$ H. WILLIAMS, Rune-stone Inscriptions and Queer Theory. (Cambridge, 2008: E.C. Quiggin Memorial
} Lectures 10), p. 9. 
"Dead in White Clothes": Modes of Christian Expression on Viking Age Rune Stones in Present-Day Sweden. Preprint version.

All of these inscriptions are from Uppland, and they are distributed throughout the 11th century, but primarily to its first half. It is indeed a fact that Christian prayers are more dominant in the early material than in the later. ${ }^{25}$ This could be given the interpretation that it was less important as time passed to demonstrate your Christian faith, presumably because it was not so exclusive any more. Towards the end of the eleventh century, when at least six out of the seven hvitavaðir stones were erected, many Upplandic families had one, two, or even three Christian generations behind them. There is a general consensus that the upper classes converted first. The rune-stones in our sample could be classified as belonging in the middle to high stratum. Especially the Uppsala Cathedral stone must have been extraordinarily impressive with a computed height of 260 centimetres and a width of almost 3 meters. This is definitely a high status monument.

Indeed it is not easy to reconcile the picture of rather advanced Christianity in 11th century Uppland with the exclusiveness of such a fundamental Christian sacrament as baptism, which would be so rare that even well-off families towards the end of the century felt motivated to boast about it.

Alexandra Sanmark, in her comparative study of the Christianization of Scandinavia points out that according to early Norwegian laws children had to be baptized within a year. ${ }^{26}$ She also writes: "In order to fulfil the requirements [...], neither churches nor priests were needed." ${ }^{27}$ No specific location was specified for the baptism ceremony and the laws make it clear that various places were used. By the use of portable altars, ${ }^{28}$ standing crosses and crossmarked stones the clergy found locations other than churches where they could perform their ceremonies. $^{29}$

Hence you do not need a church to baptize a person. In fact you do no even need a priest, not even one of the many wandering missionaries that are commonly presumed to have been extant. ${ }^{30}$ Anyone could baptize a child, also women, and not even water was necessary, sometimes even spit would do.

${ }^{25}$ F. HERSCHEND, The Recasting of a Symbolic Value - Three Case Studies on Rune-Stones (Uppsala, 1994: Occasional Papers in Archaeology 3), p. 32.

${ }^{26}$ A. SANMARK, Power and Conversion - A Comparative Study of Christianization in Scandinavia (Uppsala, 2004: Occasional Papers in Archaeology 34), p. 280 note 13, 17.

${ }^{27}$ SANMARK, Power and Conversion, p. 265.

${ }^{28}$ SANMARK, Power and Conversion, p. 270.

${ }^{29}$ SANMARK, Power and Conversion, p. 269.

${ }^{30}$ SANMARK, Power and Conversion, p. 271 and note 45, p. 285. 
"Dead in White Clothes": Modes of Christian Expression on Viking Age Rune Stones in Present-Day Sweden. Preprint version.

I simply do not understand how we could count with a settled society and one Christianized to any extent of the word without its Christian individuals fulfilling the most basic requirement of belonging to the faith, i.e. that of being baptized and baptizing your children. Baptism simply cannot have been so exclusive to be bragged about even among high status, Upplandic families almost a century after Christianity had been established in the province.

So what other possible interpretation may we give the expression dauðr i hvitavaðum?

From the quotes in Cleasby-Vigfusson's dictionary it is clear that most instances of the expression hvítaváðir do indeed refer to baptismal clothing. But there is one exception: Víga-Glúmr. As it says in the saga about him: “En pá er kristni kom út hingat, tók Glúmr Skírn ok lifði prjá vetr siðan och var byskupaðr i banasótt av Kol byskupi och andaðisk í hvítavaðum.”31 (But when Christianity came to Iceland Glum received baptism and lived for three years after that, and was confirmed during his final illness by bishop Kol and died in the white robes of a convert.) ${ }^{32}$

This is another occasion when a person dresses up in white clothes, viz. at the time of confirmation. The verb for this sacrament is ferma or biskupa in Old West Norse. In Archbishop John’s Christenret it says: “Nest skirn er hælgan su er fermingh hæitir er sumir kalla byskupan.” (“After baptism is that sanctification which is confirmation, that some call bishoping”.) ${ }^{33}$ The head line of the paragraph states: "Her segir um pa skirn er færming hætir." ("Here it is told about that baptism which is called confirmation”.) And further down we read: "Ero pessa hælganar. skirn ok færming. sua samtængdar. at huarge ma annarar missa. nema dauði kome i millum”. (“These sanctifications, baptism and confirmation, are joined in such a way that one may not miss either one of them unless death intercedes”.) Confirmation is thus also a kind of baptism and gave you the right to wear white clothes.

But, whereas baptism was very easy to come by, confirmation was quite a different matter. It could only be performed by a bishop (cf. the verb biskupa 'to bishop/confirm'), and there was no guarantee that the bishop would turn up more often than every third year even within a regular bishopric. Without a see, as in Uppland before 1060, you had to take your chances that a missionary bishop would happen to pass through your area, or you could travel

\footnotetext{
${ }^{31}$ Eyfirðingasøgur, ed. JÓNAS KRISTJÁNSSON (Reykjavík, 1956: Íslenzk fornrit 9), pp. 97-98.

${ }^{32}$ Killer-Glum's saga, transl. JOHN MCKINNELL (REYKJAVÍK, 1997: The Complete sagas of the Icelanders. Including 49 tales 2), pp. 267-314, at p. 313.

${ }^{33}$ Nyere Christenret udgiven af Erkebiskop Jon den yngre, ed. R KEYSER \& P.A. MUNCH (Christiania, 1848: Norges gamle Love intil 1387 2) , p. 344.
} 
"Dead in White Clothes": Modes of Christian Expression on Viking Age Rune Stones in Present-Day Sweden. Preprint version.

to a stationary bishop in some other part of Sweden or even abroad, for example to Denmark, where bishops were more plentiful. It is natural that people who were better off and tended to dominate the expeditions to foreign lands, as Mats G. Larsson has shown, ${ }^{34}$ stood a much better chance of travelling to a bishop than a person of less economic resources, however Christian he or she may have been.

I believe the interpretation of the expression dauðr i hvitavaðum as 'dead in white clothes (in connection with confirmation)' explains all of the characteristics of the rune-stones on which it occurs. They are Christian, probably multi-generationally, and show devout prayers in a couple of cases. They are of good status, and most of them have been associated or even signed by recognized rune masters. They are all from Uppland, where there was a Christian elite for at least two generations before the first bishopric was established in Sigtuna. (Even then not all Upplanders were close to the bishop.) In other parts of Sweden Christianity seems to have spread more rapidly with a shorter interval between introduction and full establishment, and conformation may never have been rare there.

When the literary sources constituted by Icelandic sagas, the vita Ansgarius, and various Anglo-Saxon and Continental sources describe neophytes in the 9th and 10th centuries, they are referring to the very first generation of Christians. They, of course, had to get baptized as adults. Many of them came from societies where Christianity was not established in their social group, and their parents and other family members were seldom converts. There was then no shame in being the pioneers of a new faith.

But in late 11th century Uppland Christianity was no longer news among privileged people. The parents erecting a rune-stone after a dear son or husband were obviously Christians themselves, even if only recent. If they had at all fulfilled their duties they would have had their children baptized and not let it lapse until they were close to death and then brag about it. I claim we must take it for granted that all Christian rune-stones were erected after baptized members of the faith. In six cases Upplandic men (and in one case a person of unknown sex) managed to get in contact with a bishop before dying. Two were in Denmark at the time. In all cases extraordinary efforts were motivated. The sacrament was still exclusive enough even among good Christians in Uppland to be mentioned in the obituaries. But I believe that more important was that confirmation made you sin-free for a week and thus

\footnotetext{
${ }^{34}$ M.G. LARSSON, Runstenar och utlandsfärder. Aspekter på det senvikingatida samhället med utgångspunkt i de fasta fornlämningarna (Lund, 1990: Acta Archaeologica Lundensia. Series in 8 18), p. 133.
} 
"Dead in White Clothes": Modes of Christian Expression on Viking Age Rune Stones in Present-Day Sweden. Preprint version.

exceedingly advantageous when you were about to pass away. Good Christian parents and spouses presumably felt comforted by this.

I have offered a new interpretation of the expression dauðr i hvitavaðum, an interpretation that would radically our concepts about the state of Christianity in 11th century Uppland, with far-reaching implications for the interpretation of other possible modes of expression in contemporary runic sources.

But before (and if) this new interpretation is taken as the established truth, we need to problemize it a bit. It is too easy to move from one absolute to another. The fact is we often behave as we knew everything, whereas the fact is that almost every word used in runic inscriptions is enigmatic to a greater or smaller extent. We make our comparisons, for Runic Swedish often with Old West Norse a quarter of a millennium later, from another part of North Western Europe and within a very different genre and context. Sometime those comparisons are very apt, sometime not so. We need to ask ourselves: are there other ways of understanding the expression dauðr i hvitavaðum?

A final example may be used to show that white clothes were not only used at baptism and confirmation. In Laxdola saga it is said of the Icelandic church of Borg that "pá var kirkja nývígd ok í hvítaváðum”35 “then the church was newly consecrated and in whites clothes” in connection with its consecration. This shows us that hvítaváðir were not only used at baptism and confirmation, even if the consecration of a church may symbolically be regarded as its baptism.

As for hvítaváðir the interpretation depends very much on how white garments were used in the Christian community influencing religious practices in Uppland. This I have not been able to ascertain, and in fact it is really not my task. But I might remind you that we cannot rule out influence from other Christian sources than those in Western Europe. There is also the Orthodox Church, where practices differed in some respects. And from this tradition I will quote a single example: “Johannes förberedde sig för döden i Comana, tog på sig vita kläder, tog emot kommunionen, bad för alla närvarande och gav upp andan med orden: Ära vare Gud i allting.” 36 ("John prepared himself for death in Comana, put on white clothes, received communion, prayed for all present and gave up his ghost saying: 'Glory be to God in

${ }^{35}$ Laxdoela saga. Halldórs pæettirSnorrasonar. Stúfs páttr, ed. EINAR OL. SVEINSSON (Reykjavík, 1934: Íslenzk fornrit 5), p. 158.

${ }^{36}$ O. CLÉMENT, Källor. Den kristna spiritualitetens ursprung (Skellefteå 2004), p. 344. 
"Dead in White Clothes": Modes of Christian Expression on Viking Age Rune Stones in Present-Day Sweden. Preprint version.

all things."' This is the story of the death of John Chrysostom (c. 347-407), Archbishop of Constantinople and one of the most important theologians of the Eastern Church.

I am not claiming that people in 11th century Uppland were influenced by Orthodox rather than Catholic Christianity, in fact I personally believe that was not the case. But it is not my call. We need theologians and church historians to look into the religious contents of rune stone texts before we can be sure. There has, alas, been little interest in doing this lately, and what was once done is unfortunately of substandard quality. My only hope is that this will one day change.

My point instead is that Víga-Glúmr's confirmation dress, the white robes of John Chrysostom and those of the church in Borg show us that it is dangerous to take a translation of a rune stone text for granted. All we know for certain is that seven Viking age Upplanders died in white textiles. We need to look at all the facts before deciding what kind of textiles that would provide the best explanation. I suggest that it may be the white clothes used at confirmation.

It has, however, been claimed that baptism could only be done by a bishop, ${ }^{37}$ which would then, of course, make it a very exclusive event and certainly worth mentioning on a rune stone. It is doubtful if there are any real grounds for such an assumption. That the Church originally required bishops to perform baptisms is quite clear, but equally clear is that this practice was not always adhered to. ${ }^{38}$ I also think that it is vital to remember that what was the norm in well-ordered parishes on the Continent and in the British Isles in the 9th century does not automatically ensure that the same was true of 11th century Sweden.

But this is a problem for theologians to solve. Their answer will affect our understanding of Runic expressions and practices and their relationship to Christianity.

${ }^{37}$ B. JOHANSEN, Ormalur. Aspekter av tillvaro och landskap (Stockholm 1997: Stockholm Studies in Archaeology 14) ,p. 240; L. MEJSHOLM, Gränsland. Konstruktionen av tidig barndom och begravningsritual vid tiden för kristnandet i Skandinavien, (Uppsala, 2009: Occasional Papers in Archaeology 44), p. 119.

${ }^{38}$ J.D.C. FISHER, Christian Initiation: Baptism in the Medieval West. A Study in the disintegration of the Primitive Rite of Initiation (London, 1965: Alcuin Club Collections 47), pp. 19, 38, 45, 53-54., 56, 63. 